KONSTRUKTIVISME, Vol. 7, No. 2, Juli 2015

p-ISSN: 1979-9438, e-ISSN: 2445-2355

FKIP Universitas Islam Balitar, Blitar

Web: konstruktivisme.unisbablitar.ejournal.web.id

\title{
MENINGKATKAN HASIL BELAJAR KOGNITIF SISWA DAN AKTIVITAS GURU PADA MATERI BIOTEKNOLOGI PANGAN KELAS IX MTS MELALUI MODEL PEMBELAJARAN BERBASIS MASALAH
}

\author{
Dwi Kameluh Agustina \\ Pendidikan Biologi \\ Universitas Islam Balitar \\ Jl. Mojopahit 2-4 Blitar
}

Email: dkameluhagustina@gmail.com

\begin{abstract}
This study is aimed at seeing improvement of studnets cognitive learning achievement and teacher activities in food biotechnology subject. The study used Classroom Action Research with two cycles and assigned 30 students of the IX grade of MTs Sunan Ampel, Siman Kepung in 2014/2015. Data were colledted using test and observation. The study found that teaching model using problem-based learning improves teachers' classroom activities. Cycle I found students activity $62.5 \%$ (fair) increasing to $69.7 \%$ (good) in cycle II. Learning mastery increased from $52 \%$ in cycle I into $85 \%$ in cycle II. Students supplied positive responses on the implementation of problem-based learning model in teaching food biotechnology.
\end{abstract}

Keywords: teacher activities, learning achievement, problembased learning.

\begin{abstract}
Abstrak
Penelitian ini bertujuan untuk melihat peningkatan hasil belajar kognitif siswa dan aktivitas guru pada materi bioteknologi pangan. Penelitian menggunakan rancangan Penelitian Tindakan Kelas dua siklus dan subjek penelitian siswa kelas IX MTs Sunan Ampel Siman Kepung Tahun Pelajaran 2014/2015 berjumlah 30 siswa. Data dikumpulkan menggunakan tes tertulis dan observasi. Hasil penelitian menunjukkan bahwa Model Pembelajaran Berbasis Masalah Materi Bioteknologi Pangan yang diterapkan pada siswa dapat meningkatkan aktivitas guru. Pada siklus I, aktivitas siswa mencapai $62,5 \%$ (cukup) naik menjadi 69,7\% (baik) pada siklus II. Ketuntasan hasil belajar meningkat dari $52 \%$ pada siklus I menjadi $85 \%$ pada siklus II. Respon siswa terhadap penerapan pembelajaran berbasis masalah pada Bioteknologi Pangan adalah positif.
\end{abstract}

Kata kunci: Aktivitas Guru, Hasil Belajar Siswa, Pembelajaran Berbasis Masalah. 
Bioteknologi pangan merupakan materi pelajaran IPA di kelas IX SMP/MTs yang menuntut siswa untuk memahami proses pengolahan bahan pahan melalui bioteknologi. Selain itu, materi tersebut menggugah siswa utuk mampu mengemukakan permasalahan, mengemukakan ide dan pendapatnya, serta menganalisis dan mengevaluasi pemecahan masalah khususnya yang berkaitan dengan konsep bioteknologi pangan dan pengolahannya.

Pengamatan secara langsung oleh siswa sangat perlu dilakukan baik dengan mendorong siswa melakukan eksperimen atau menggali informasi melalui media agar siswa berpikir konkrit dan mengerti secara langsung tentang pemecahan masalah yang dihadapi. Menurut Trianto (2009: 8-9) siswa diharapkan aktif dalam pembelajaran, dalam upaya mencari jawaban sendiri atas permasalah yang timbul. Ketika mengajar di kelas, guru harus berupaya menciptakan kondisi lingkungan belajar yang dapat membelajarkan siswa, dapat mendorong siswa belajar, atau memberi kesempatan kepada siswa untuk berperan aktif mengkonstruksi konsep yang dipelajarinya. Salah satu model pembelajaran inovatif yang dapat memberikan kondisi belajar aktif kepada siswa adalah Pembelajaran Berbasis Masalah (Problem-Based Learning). Menurut Arends (2008:41), Pembelajaran Berbasis Masalah (Problem-Based Learning) menuntut peran guru untuk menyodorkan berbagai masalah autentik, memfasilitasi penyelidikan siswa dan mendukung pembelajaran siswa sehingga mereka terdorong berperan aktif dalam belajar.

Hasil observasi di MTs. Sunan Ampel Siman Kepung, diketahui bahwa nilai rata-rata ulangan harian pada materi tersebut sebesar 65, sedangkan Kriteria Ketuntasan Minimal (KKM) adalah sebesar 70, berarti dapat dikatakan hasil belajar siswa pada kompetensi dasar tersebut masih rendah. Beberapa faktor yang diduga sebagai penyebab rendahnya hasil belajar siswa adalah siswa menganggap materi pelajaran tersebut sulit dipahami, selain itu, berdasarkan wawancara dengan guru IPA kelas VII MTs. Sunan Ampel Siman Kepung dalam pembelajarannya jarang memanfaatkan media pembelajaran misalnya, video pembelajaran, media yang biasanya digunakan hanya memanfaatkan gambar-gambar yang ada pada buku paket pelajaran, sedangkan untuk melakukan pengamatan secara langsung tentang pengolahan bahan pahan melalui keilmuan bioteknologi sangat kurang akibat keterbatasan waktu atau jam pelajaran yang sudah diprogramkan.

Penelitian ini memiliki tujuan sebagai berikut: (1). untuk meningkatkan hasil belajar kognitif siswa kelas IX MTs. Sunan Ampel Siman Kepung. (2). untuk meningkatkan aktivitas guru IPA kelas IX MTs. Sunan Ampel Siman Kepung pada materi Bioteknologi Pangan. 
Agustina, Kameluh Dwi. 2015. Meningkatkan Hasil Belajar Kognitif Siswa 109 dan Aktifitas Guru pada Materi Bioteknologi Pangan Kelas IX MTs Melalui Model Pembelajaran Berbasis Masalah. Konstruktivisme, 7(2):107-118.

\section{METODE}

\section{Pendekatan dan Jenis Penelitian}

Penelitian adalah Penelitian Tindakan Kelas, karena penelitian yang dilakukan oleh peneliti dilaksanakan secara langsung di dalam kelas pada saat proses belajar mengajar.

Siklus PTK diawali dengan perencanaan tindakan (planning), penerapan tindakan (action), mengobservasi dan mengevaluasi proses dan hasil tindakan (observation and evaluation), dan melakukan refleksi (reflection), dan seterusnya sampai perbaikan atau peningkatan yang diharapkan tercapai (kriteria keberhasilan). Dalam penelitian ini siswa diberi perlakuan yaitu dengan menerapkan model Pembelajaran Berdasarkan Masalah, dan guru sebagai mediator dan fasilitator pembelajaran.

Alur penelitian tindakan kelas pada penelitian ini dijelaskan pada gambar 1 sebagai berikut.

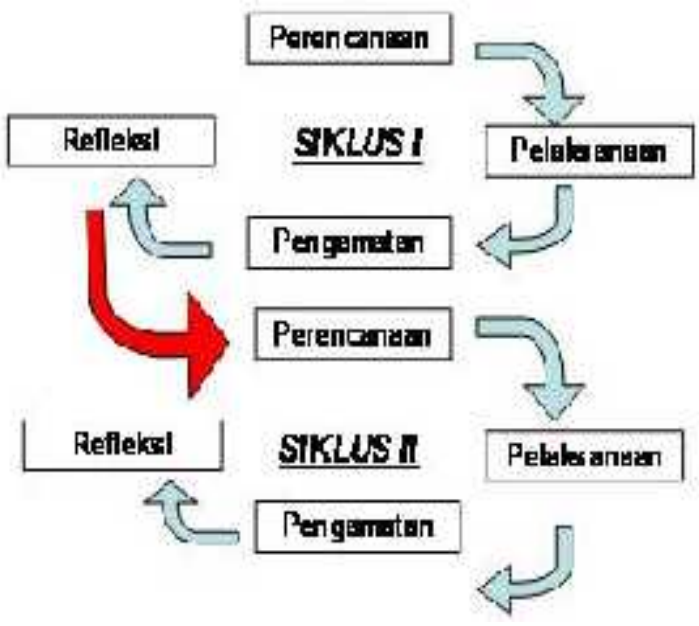

Gambar 1. Alur Penelitian Tindakan Kelas

(Sumber: Arikunto, 2010:16)

\section{Waktu dan Tempat Penelitian}

Waktu dilaksanakannya penelitian ini adalah pada semester genap tahun pelajaran $2014 / 2015$, berlangsung selama 2 bulan yaitu pada bulan Mei s/d Juli 2015. Tempat berlangsungnya penelitian ini adalah di MTs. Sunan Ampel Siman Kepung.

\section{Subyek Penelitian}

Siswa yang dijadikan subyek peneltian ini adalah siswa kelas IX MTs. Sunan Ampel Siman Kepung Tahun Pelajaran 2014/2015 yang berjumlah 30 orang siswa, terdiri dari 13 siswa laki-laki dan 17 siswa perempuan.

\section{Prosedur Penelitian}

Penelitian ini dilaksanakan dengan menggunakan desain penelitian tindakan kelas yang peniliti menjadi siklus I dan II. Masing-masing siklus 
terdiri dari perencanaan (planning), pelaksanaan tindakan (acting), pengamatan (observing), dan refleksi (reflecting). Secara jelasnya prosedur pelaksanaan penelitian siklus I dan siklus II akan diuraikan sebagai berikut:

\section{Pelaksanaan Siklus I}

\section{a. Perencanaan} berikut:

Hal-hal yang dilakukan pada tahap perencanaan adalah sebagai

1) Menyusun Silabus, Rencana Pelaksanaaan Pembelajaran (RPP) dan LKPD,.

2) Menyusun instrumen penilaian hasil belajar, yaitu berupa soal pretes dan postes beserta kunci jawabannya.

3) Menyiapkan lembar penilaian aktivitas siswa beserta rubrik penilaiannya.

4) Menyiapkan lembar penilaian aktivitas guru dan rubrik penilaiannya.

5) Menyiapkan lembar pengamatan prilaku karakter dan keterampilan sosial siswa beserta rubrik penilaiannya.

Selanjutnya instrumen yang disiapkan pada tahap perencanaan didiskusikan dengan guru IPA kelas kelas IX MTs. Sunan Ampel Siman Kepung apabila ada kekurangan peneliti melengkapi dan memperbaikinya.

\section{b. Pelaksanaan Tindakan}

Pada Tahap ini guru IPA kelas kelas IX MTs. Sunan Ampel Siman Kepung sebagai guru model, melaksanakan proses belajar mengajar sesuai dengan RPP yang telah disusun dengan langkah pokok sebagai berikut:

1) Melakukan apersepsi dan memberikan motivasi belajar siswa dengan mengemukakan isu atau masalah aktual yang ada dimasyarakat dan mampu diamati oleh siswa serta relevan dengan materi yang akan diajarkan "Bioteknologi Pangan".

2) Menyampaikan tujuan pembelajaran yang ingin dicapai dan langkahlangkah kegiatan pembelajaran.

3) Melakukan pretest kepada siswa.

4) Guru menyajikan informasi atau materi secara umum kepada siswa lewat bahan bacaan.

5) Mengelompokkan siswa dalam kelompok belajar yang terdiri dari 4 atau 5 orang siswa secara heterogen.

6) Guru Membagikan LKPD yang sesuai dengan materi pada masingmasing kelompok dan menjelaskan maksud, tujuan dan cara kerja di dalam LKPD.

7) Siswa menyelesaikan masalah yang menganalisis masalah atau isu yang telah dikemukakan di awal pembelajaran berdasarkan konsep yang telah dipahami sebelumnya dengan mengerjakan LKPD.

8) Guru membimbing kelompok-kelompok dalam menyelesaikan masalah yang ada pada LKPD.

9) Setiap kelompok mempersentasikan hasil jawaban LKPD nya masingmasing. 
Agustina, Kameluh Dwi. 2015. Meningkatkan Hasil Belajar Kognitif Siswa 111 dan Aktifitas Guru pada Materi Bioteknologi Pangan Kelas IX MTs Melalui Model Pembelajaran Berbasis Masalah. Konstruktivisme, 7(2):107-118.

10) Guru besama-sama siswa menyimpulkan materi pelajaran dan memberipemantapan konsep agar tidak terjadi kesalahan konsep pada siswa.

11) Melakukan postes, setelah pembelajaran.

12) Guru memberikan penghargaan kepada kelompok-kelompok yang hasil kerjanya baik.

\section{c. Pengamatan (observation)}

Pengamatan atau observasi dilaksanakan selama penelitian berlangsung, dengan sasaran utama untuk melihat peningkatan keterampilan proses sains siswa dalam pembelajaran IPA konsep materi Bioteknologi Pangan dan hasil pemahaman konsep siswa terhadap materi tersebut, serta aktivitas guru dalam melaksanakan Rencana Pelaksanaan Pembelajaran (RPP) yang telah disusun. Kegiatan obsevasi dilakukan oleh 2 orang observer.

\section{d. Refleksi (reflection)}

Refleksi dilaksanakan setiap akhir siklus. Hasil yang diperoleh dalam tahap observasi melalui lembar pengamatan berdasarkan insrumen yang telah disusun, kemudian dikumpulkan serta dianalisis, demikian pula dengan tes belajar siswa. Demikian peneliti dapat melihat sejauh mana ketercapaian dari rencana tindakkan dan mendiskusikan bilamana terdapat permasalahan dari pelaksanaan siklus I yang nantinya akan ditindak lanjuti pada siklus II.

\section{Pelaksanaan Siklus II}

Prosedur penelitian pada siklus II pada dasarnya sama dengan prosedur penelitian pada siklus I, perbedaannya adalah :

a. Pada tahap perencanan, selain menyiapkan semua instrument penelitian untuk

siklus II, peneliti juga menyiapkan lembar angket respon siswa.

b. Materi pelajaran yang disajikan merupakan kelanjutan dari bahan ajar yang telah diberikan pada siklus I.

c. Pelaksanaan tindakan siklus II mempertimbangkan hasil refleksi siklus I, dan pada akhir kegiatan siklus II.

d. Pada akhir kegiatan penelitian, siswa diberikan angket siswa untuk mengetahui respon mereka terhadap pelaksanaan pembelajaran.

\section{Jenis dan Teknik Pengumpulan Data}

Jenis data dalam penelitan ini dan cara mendapatkannya adalah sebagai berikut:

1. Hasil Belajar Kognitif Siswa

Data ini berupa nilai (hasil) pemahaman siswa pada materi konsep PencemaranLingkungan, diperoleh melalui tes yang dilaksanakan baik sebelum kegiatan pembelajaran (pretes) maupun setelah kegiatan pembelajaran (postes) dengan menggunakan lembar penilaian produk berupa soal pretes dan postes.

2. Akivitas Guru 
Data ini berupa aktivitas guru selama mengikuti kegiatan pembelajaran dan aktivitas guru dalam melaksanakan kegiatan pembelajaran dengan menggunakan Model Pembelajaran Berdasarkan Masalah. Data tersebut diperoleh melalui kegiatan pengamatan dengan menggunakan lembar observasi aktivitas guru.

3. Respon Siswa

Data tentang respon (tanggapan) siswa terhadap pelaksanaan kegiatan pembelajaran diperoleh melalui pemberian angket kepada semua siswa setelah penelitian selesai.

\section{Teknik Analisis Data}

Teknik analisis data yang digunakan antara lain :

1. Teknik analisis data pemahaman siswa ini merupakan analisis data kuantitatif, dengan cara menghitung ketuntasan individual dan ketuntasan klasikal pada konsep pembelajaran "Bioteknologi Pangan" berdasarkan nilai siswa yang diperoleh. Adapun rumus yang digunakan adalah sebagai berikut:

nilai siswa $=\frac{\text { skor perolehan }}{\text { skor maksimal }} x 100$

Untuk menghitung ketuntasan belajar secara klasikal menggunakan rumus sebagai berikut:

$$
\text { Ketuntasan Klasikal }=\frac{\text { Jumlahsiswayangtuntas }}{\text { Jumlahsiswakesoluruhan }} \times 100
$$

(Sumber; Trianto, 2012; 241).

2. Teknik analisis data proses pembelajaran guru merupakan analisis data kuantitatif, dengan cara mendeskripsikan hasil dari lembar obsevasi berdasarkan pedoman yang ada pada rubrik penilaian. Obsevasi dilakukan oleh dua orang pengamat yaitu peneliti sendiri dan teman sejawat.

\section{Indikator Keberhasilan}

Penelitian ini dikatakan berhasil apabila mencapai ketuntasan sebagai berikut:

1. Peningkatan pemahaman siswa dengan tercapainya hasil belajar siswa yaitu:

a. Pemahaman individu tercapai bila nilai akhir siswa mendapat nilai $\geq 70$ sesuai dengan Kreteria Ketuntasan Minimun (KKM) Mata pelajaraan IPA di kelas IX MTs. Sunan Ampel Siman Kepung untuk konsep Bioteknologi Pangan.

b. Pemahaman siswa secara klasikal tercapai bila terdapat $80 \%$ siswa yang mencapai Kriteria Ketuntasan Minimum (KKM) Mata Pelajaran IPA kelas IX MTs. Sunan Ampel Siman Kepung. 
Agustina, Kameluh Dwi. 2015. Meningkatkan Hasil Belajar Kognitif Siswa 113 dan Aktifitas Guru pada Materi Bioteknologi Pangan Kelas IX MTs Melalui Model Pembelajaran Berbasis Masalah.

Konstruktivisme, 7(2):107-118.

Penilaian pemahaman dikatakan berhasil apabila peningkatan hasil belajar dari Siklus I dan Siklus II mengalami peningkatan minimal $10 \%$.

2. Keterlaksanaan Proses Pembelajaran guru, terhadap penerapan Model Pembelajaran Berbasis Masalah diinterpretasikan dapat dilihat pada tabel berikut:

Tabel 1. Kualifikasi Aktivitas Guru

\begin{tabular}{cc}
\hline Interval & Kategori \\
\hline $81-100$ & Amat Baik \\
$70-80$ & Baik \\
$\leq 69$ & Cukup \\
\hline
\end{tabular}

(Sumber: Trianto, 2010: 38)

\section{Respon Siswa}

Data tentang respon (tanggapan) siswa terhadap pelaksanaan kegiatan pembelajaran diperoleh melalui pemberian angket kepada semua siswa setelah penelitian selesai dan terdapat $75 \%$ siswa senang dan termotivasi dalam pembelajaran.

\section{HASIL}

\section{Siklus I}

\section{Hasil Belajar Kognitif Siswa Siklus I}

Hasil belajar dalam penelitian ini adalah Hasil Belajar Ranah Kognitif yaitu Produk pemahaman siswa terhadap materi pelajaran. Penilaian hasil belajar ranah kognitif produk dilakukan dengan melaksanakan evaluasi tertulis berupa Soal tes berbentuk pilihan ganda dengan 4 pilihan jawaban pada pretes dan postes. Ringkasan data hasil pretes dan postes siklus I dilihat pada Tabel 2. berikut ini:

Tabel 2. Ringkasan Data Hasil Pretes dan Postes Siklus I

\begin{tabular}{|l|c|c|}
\hline \multicolumn{1}{|c|}{$\begin{array}{c}\text { Hasil Belajar } \\
\text { Produk }\end{array}$} & Pretes & Postes \\
\hline Rata-rata Nilai & 53,5 & 74,2 \\
\hline $\begin{array}{l}\text { Jumlah siswa yang } \\
\text { tuntas }\end{array}$ & 7 & 15 \\
\hline $\begin{array}{l}\text { Jumlah siswa yang } \\
\text { tidak tuntas }\end{array}$ & 23 & 25 \\
\hline $\begin{array}{l}\% \text { Ketuntasan } \\
\text { klasikal }\end{array}$ & $23 \%$ & $50 \%$ \\
\hline
\end{tabular}

Berdasarkan Tabel 2 data pretes diketahui jumlah siswa yang tuntas hanya 7 orang siswa dari 30 yang mengikuti pretes dengan ketuntasan klasikal $23 \%$. Data hasil postes mengalami peningkatan yakni 15 orang siswa yang tuntas dengan ketuntasan klasikanya $50 \%$. 
Persentase ketuntasan klasikal hasil pretes maupun postest pada siklus I belum mencapai kreteria ketuntasan yaitu minimal $80 \%$. Sehingga perlu diperbaiki pada siklus II.

\section{Aktivitas Guru Siklus I}

Pada kegiatan pembelajaran dengan menggunakan model pembelajaran berbasis masalah, digunakan lembar observasi guru untuk mengamati kegiatan pembelajaran atau aktivitas yang dilakukan guru. Lembar observasi terdiri dari 12 aspek yang diamati oleh dua orang observer. Pada setiap aspek terdapat empat kriteria penilaian yaitu : nilai 4; jika dilakukan sesuai prosedur, 3; Jika dilakukan sebagian sesuai prosedur, 2; Jika dilakukan sebagian kecil, 1; Jikatidak dilakukan sama sekali.

Skor penilaian aktivitas guru kemudian dijumlah dan dihitung dengan teknik persentase. Ringkasan hasil penilaian aktivitas guru pada siklus I dilihat dari Tabel 2 yang disajikan berikut ini.

Tabel 3. Ringkasan Data Hasil Pengamatan Aktivitas Guru Siklus I

\begin{tabular}{|l|c|c|c|c|}
\hline \multirow{2}{*}{ Aktivitas Guru } & \multicolumn{2}{|c|}{ Pertemuan 1 } & \multicolumn{2}{c|}{ Pertemuan 2 } \\
\cline { 2 - 5 } & $\begin{array}{l}\text { Pengamat } \\
1\end{array}$ & Pengamat 2 & $\begin{array}{l}\text { Pengam } \\
\text { at 1 }\end{array}$ & Pengamat 2 \\
\hline Jumlah & 30 & 30 & 34 & 33 \\
\hline Rata-rata skor & 2,5 & 2,5 & 2,8 & 2,75 \\
\hline $\begin{array}{l}\text { Jumlah Pengamat } \\
1 \text { \&2 }\end{array}$ & \multicolumn{2}{|c|}{60} & \multicolumn{2}{c|}{77} \\
\hline Skor Maksimasl & \multicolumn{2}{|c|}{96} & \multicolumn{2}{c|}{69,7 (Baik) } \\
\hline Nilai & \multicolumn{2}{|c|}{62,5 (Cukup) } \\
\hline $\begin{array}{l}\text { Nilai } \\
\text { Siklus I }\end{array}$
\end{tabular}

\section{Refleksi}

Berdasarkan analisis data hasil belajar siswa dan aktivitas guru pada siklus I dapat disimpulkan secara keseluruhan belum memenuhi kreteria indikator ketercapaian yang telah ditetapkan pada penelitian ini. Dengan demikian perlu dilanjutkan pada siklus II untuk memperoleh hasil yang maksimal dilakukan refleksi guna perbaikan tindakan pada siklus II.

Hasil refleksi siklus I disajikan sebagai berikut:

1. Aktivitas guru harus ditingkatkan lagi sesuai dengan prosedur Rencana Pelaksanaan Pembelajaran (RPP) menggunakan model Pembelajaran Berdasarkan Masalah, Peneliti merancang dan menyiapkan RPP yang lebih rinci agar dapat dilaksanakan pada siklus II dengan lebih baik lagi.

2. Hasil belajar produk, siswa diberi tugas bahan bacaan yang berkaitan dengan materi pelajaran pada sklus II sehingga dapat mempersiapkan diri belajar sebelum dilakukan siklus II. 
Agustina, Kameluh Dwi. 2015. Meningkatkan Hasil Belajar Kognitif Siswa 115 dan Aktifitas Guru pada Materi Bioteknologi Pangan Kelas IX MTs Melalui Model Pembelajaran Berbasis Masalah.

Konstruktivisme, 7(2):107-118.

\section{Siklus II}

\section{Hasil Belajar Kognitif SiswaSiklus II} pada tabel 4.

Ringkasan data hasil pretes dan postes pada siklus II dapat dilihat

Berdasarkan Tabel 4 data diketahui jumlah siswa yang tuntas 17 dari 30 siswa yang mengikuti pretes atau ketuntasan klasikal 57\%. Data hasil postes mengalami peningkatan yakni 26 siswa yang tuntas atau ketuntasan klasikanya $86 \%$. Persentase ketuntasan klasikal hasil postest pada siklus II ini mencapai kriteria ketuntasan yang ditetapkan yaitu minimal $80 \%$.

Tabel 4. Ringkasan Data Hasil Pretes dan Postes Siklus II

\begin{tabular}{|l|c|c|}
\hline \multicolumn{1}{|c|}{ Hasil Belajar (Produk) } & Pretes & Postes \\
\hline Rata-rata Nilai & 63,15 & 84,2 \\
\hline Jumlah siswa yang tuntas & 17 & 26 \\
\hline $\begin{array}{l}\text { Jumlah siswa yang tidak } \\
\text { tuntas }\end{array}$ & 13 & 4 \\
\hline$\%$ Ketuntasan klasikal & $57 \%$ & $86 \%$ \\
\hline
\end{tabular}

\section{Aktivitas Guru Siklus II}

Data hasil penilaian aktivitas guru pada siklus II dilihat dari Tabel 5 yang disajikan berikut ini.

Tabel 5. Ringkasan Data Hasil Pengamatan Aktivitas Guru Siklus II

\begin{tabular}{|c|c|c|c|c|}
\hline \multirow[b]{2}{*}{ Aktivitas Guru } & \multicolumn{2}{|c|}{ Pertemuan 3} & \multicolumn{2}{|c|}{ Pertemuan 4} \\
\hline & $\begin{array}{l}\text { Pengamat } \\
1\end{array}$ & \begin{tabular}{|l} 
Pengamat \\
2
\end{tabular} & $\begin{array}{l}\text { Pengamat } \\
1\end{array}$ & $\begin{array}{l}\text { Pengamat } \\
2\end{array}$ \\
\hline Jumlah & 38 & 37 & 39 & 39 \\
\hline Rata-rata skor & 3,2 & 3,1 & 3,25 & 3,25 \\
\hline $\begin{array}{l}\text { Jumlah Pengamat } \\
1 \& 2\end{array}$ & \multicolumn{2}{|c|}{75} & \multicolumn{2}{|c|}{78} \\
\hline Skor Maksimasl & \multicolumn{2}{|c|}{96} & \multicolumn{2}{|c|}{96} \\
\hline Nilai & \multicolumn{2}{|c|}{ 78,2 (Baik) } & \multicolumn{2}{|c|}{81.25 (Baik) } \\
\hline $\begin{array}{ll}\text { Nilai } & \text { Rata-rata } \\
\text { Siklus I } & \\
\end{array}$ & \multicolumn{4}{|c|}{ 79,7 (Baik) } \\
\hline
\end{tabular}

\section{BAHASAN}

\section{Hasil Belajar Kognitif Siswa}

Ringkasan data hasil pretes dan postes siklus I dan Siklus II untuk lebih jelasnya dapat dilihat pada Tabel 6 sebagai berikut. 
Tabel 6. Hasil Belajar Siswa Ranah Kognitif Produk Siklus I dan Siklus II

\begin{tabular}{ccccc}
\hline \multirow{2}{*}{ Hasil Tes } & \multicolumn{2}{c}{ Siklus I } & \multicolumn{2}{c}{ Siklus II } \\
\cline { 2 - 5 } & Pretest & $\begin{array}{c}\text { Post } \\
\text { test }\end{array}$ & Pretest & Post test \\
\hline $\begin{array}{c}\text { Jumlah Siswa } \\
\text { TidakTuntas }\end{array}$ & 7 & 15 & 17 & 26 \\
\hline Jumlah Siswa Tuntas & 23 & 25 & 13 & 4 \\
\hline \% Ketuntasan Klasikal & $23 \%$ & $50 \%$ & $57 \%$ & $86 \%$ \\
\hline
\end{tabular}

Sumber: Data Tabel 2 dan Tabel 4.

Berdasarkan data Tabel 6, diperoleh grafik hasil belajar siswa produk pada siklus I dan siklus II dapat dilihat seperti pada Gambar 2 berikut ini:

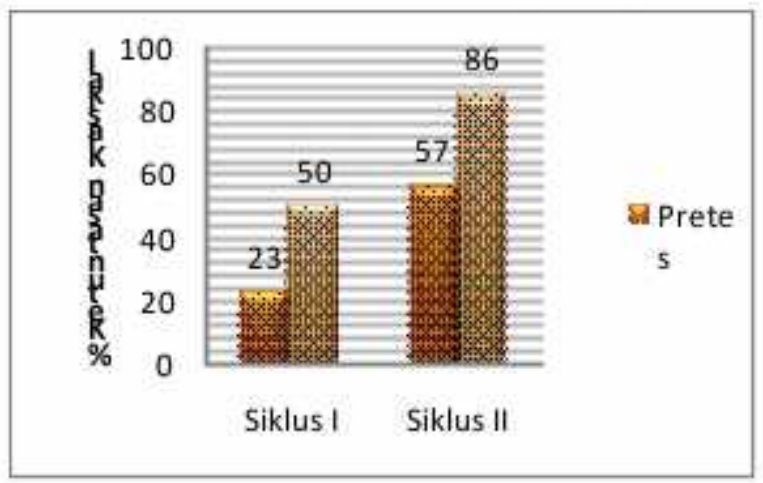

Gambar 2. Grafik Hasil Belajar Siswa Ranah Kognitif Produk

Berdasarkan Tabel 6 dan Gambar 2 tentang hasil belajar siswa ranah kognitif produk dapat dilihat bahwa terjadi peningkatan hasil belajar siswa pada ranah kognitif produk dari siklus I dan II. Dilihat dari grafik diagram batang, pretest pada siklus I dengan ketuntasan klasikal $23 \%$ dan pretest pada siklus II dengan ketuntasan klasikal 57\%. Ini menunjukkan terjadi peningkatan pretest pada siklus I ke siklus II. Pada post test siklus I ketuntasan klasikal menunjukkan $52 \%$ meningkat menjadi $86 \%$ di siklus II.

Berdasarkan tabel 6 hasil analisis data pada pelaksanaan pembelajaran siklus I, penerapan model pembelajaran berbasis masalah (PBM) pemahaman siswa terhadap materi bioteknologi pangan, pada pretes siklus I yang memperoleh sebesar $23 \%$, sedangkan hasil postesnya ketuntasan belajar klasikal hanya $50 \%$. Secara persentase ketuntasan klasikal baik nilai pretest maupun postes pada siklus I, namun belum memenuhi syarat ketuntasan klasikal $85 \%$. Setiap siswa dikatakan tuntas belajarnya (ketuntasan individu) jika proporsi jawaban benar siswa $\geq \mathrm{KKM}$, dan suatu kelas dikatakan tuntas belajarnya (ketuntasan klasikal) jika dalam kelas tersebut terdapat $\geq 85 \%$ siswa yang telah tuntas belajarnya (Depdikbud dalam Trianto, 2010:241).

Tidak tecapainya ketuntasan hasil belajar kognitif produk berupa pemahaman materi bioteknologi pangan pada siklus I dimungkinkan karena 
Agustina, Kameluh Dwi. 2015. Meningkatkan Hasil Belajar Kognitif Siswa 117 dan Aktifitas Guru pada Materi Bioteknologi Pangan Kelas IX MTs Melalui Model Pembelajaran Berbasis Masalah.

Konstruktivisme, 7(2):107-118.

siswa belum siap dan belum terbiasa dengan model pembelajaran berbasis masalah yang diterapkan sehingga siswa tidak dapat secara utuh memahami materi pelajaran yang sedang dipelajarinya. Demikian halnya dengan guru yang belum terbiasa melaksanakan model pembelajaran berbasis masalah tampak masih kesulitan menggunakan model ini, sehingga sebagian besar siswa kurang serius dan termotivasi mengikuti pembelajaran sehingga hasil belajar pada siklus I rendah.

Pada siklus II hasil belajar siswa sudah mengalami peningkatan dibandingkan siklus I. Dari nilai pretes siswa pada siklus II terdapat 17 siswa yang memperoleh nilai diatas KKM atau 57\% siswa dikategorikan tuntas, sedangkan data hasil postes terdapat $87 \%$ atau 26 siswa tuntas. Dengan demikian pada hasil postes siklus II dapat dikatakan pembelajaran berbasis masalah yang diterapkan sudah mencapai ketuntasan klasikal. Hal ini disebabkan guru telah melaksanakan RPP pembelajaran dengan baik.

\section{Aktivitas Guru}

Berdasarkan hasil observasi kegiatan belajar mengajar guru diperoleh hasil dua orang pengamat seperti disajikan pada Tabel 7 sebagai berikut:

Tabel 7. Penilaian Aktivitas Guru Siklus I dan Siklus II

\begin{tabular}{|c|c|c|c|c|}
\hline \multirow{2}{*}{$\begin{array}{c}\text { Penilaian } \\
\text { Aktivitas } \\
\text { Guru }\end{array}$} & \multicolumn{2}{|c|}{ Siklus I } & \multicolumn{2}{|c|}{ Siklus II } \\
\hline & $\begin{array}{c}\text { Pertemuan } \\
1\end{array}$ & $\begin{array}{c}\text { Pertemuan } \\
2\end{array}$ & $\begin{array}{c}\text { Pertemuan } \\
3\end{array}$ & $\begin{array}{c}\text { Pertemuan } \\
4\end{array}$ \\
\hline Nilai & 66,5 & 69,7 & 78,2 & 81,2 \\
\hline $\begin{array}{l}\text { Rata- } \\
\text { Rata }\end{array}$ & \multicolumn{2}{|c|}{66,1} & \multicolumn{2}{|c|}{79,7} \\
\hline Kategori & \multicolumn{2}{|c|}{ Cukup } & \multicolumn{2}{|c|}{ Baik } \\
\hline
\end{tabular}

Sumber Data: Tabel 3 dan Tabel 5

Berdasarkan Tabel 7 di atas, Siklus I pertemuan 1 memperoleh nilai 66,5 kategori cukup pertemuan 2 memperoleh nilai 69,7 kategori baik dan pada siklus II pertemuan 3 memperoleh nilai 78,2 kategori baik sedangkan siklus II pertemuan 4 memperoleh nilai 81,2 juga pada kategori Baik. Secara Nilai rata-rata aktivitas guru pada siklus I adalah 66,1 kategori Cukup dan mengalami peningkatan pada siklus II dengan nilai 79,7 kategori Baik. Peningkatan ini terjadi karena guru semakin memahami langkah pembelajaran berdasarkan masalah dan menerapkan pembelajaran dengan baik sesuai dengan rencana pembelajaran.

Berdasarkan data dari Tabel 7 di atas dapat dilihatgrafik penilaian aktivitas guru pada siklus I dan siklus II pada Gambar 3 yang disajikan berikut ini: 


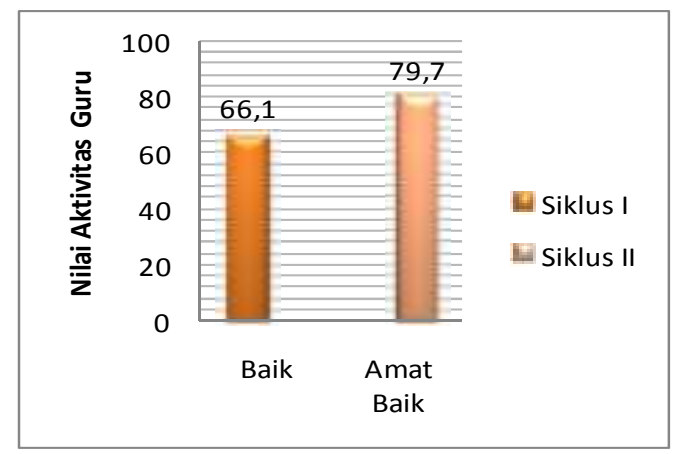

Gambar 3. Grafik Penilaian Aktivitas Guru

Berdasarkan Gambar 3, dapat dilihat aktivitas guru dilakukan sesuai dengan langkah-langkah model pembelajaran berdasarkan masalah (PBM) yang terdapat di dalam RPP. Penilaian aktivitas guru tersebut didapat dari hasil observasi dengan melakukan pengamatan terhadap guru yang dilaksanakan pada setiap siklusnya. Aktivitas guru dengan nilai 66,1 dengan berada pada kategori cukup meningkat menjadi 79,7 warna biru pada siklus II yang menunjukkan aktvitas guru dengan kategori Baik.

\section{SIMPULAN}

Berdasarkan hasil penelitan dan pembahasan dapat disimpulkan sebagai berikut:

1. Hasil Belajar kognitif produk siswa mengalami peningkatan. Persentase siswa tuntas mengalami peningkatan pada siklus I dan siklus II. Pada siklus I dari rata-rata hasil pretes sebesar $23 \%$ meningkat menjadi $50 \%$. Sedangkan pada siklus II hasil postesnya $57 \%$ meningkat menjadi $85 \%$. .

2. Aktivitas guru dalam melaksanakan pembelajaran berdasarkan masalah meningkat dari siklus I 66,1\% kategori cukup menjadi 79,7\% dengan kategori baik pada siklus II.

\section{DAFTAR PUSTAKA}

Arikunto, Suharsimi. 2010. Penelitian Tindakan Kelas. Jakarta: Bumi Aksara.

Arends, R. I. 2008. Learning to Teach. (Terjemahan Helly Prayitno Soetjipto \& Sri Mulyani Soetjipto). New York: McGraw Hill Companies. (Buku asli diterbitkan tahun 1997).

Trianto. 2010. Mendesain Model Pembelajaran Inovatif-Progresif. Jakarta: Kencana Prenada Media Group. 